\title{
Farm Practices and Policies for Mitigating N Leaching and Run-Off: A Review
}

\author{
D. Blaise*, A. Manikandan, K. Velmourougane \\ Division of Crop Production, ICAR-Central Institute for Cotton Research, \\ Nagpur-440010, Maharashtra, India
}

\begin{abstract}
Leaching of fertilizer $\mathrm{N}$ as nitrate pollutes groundwater. Further, surfaceapplied fertilizers can be lost through run-off following water erosion and contaminates surface water bodies. Quantity of $\mathrm{N}$ lost through leaching and surface run-off would depend on the agro-ecosystem. The probable safe limit of nitrates in groundwater based on available literature is 45 to $50 \mathrm{mgL}^{-1}$. The present practices and their influence of $\mathrm{N}$ loss, the strategies to mitigate leaching and run-off in order to improve nitrogen use efficiency and challenges are discussed.
\end{abstract}

Keywords: $N$ leaching, ground water, agro-ecosystem, mitigation strategies, policies

\section{Introduction}

Fertilizer-N has been one of the key production inputs that resulted in enhancing crop productivity. Fertilizer use increased 135 fold during 1950-51 to 2014-15. One of the major reasons for a quantum jump in yields with fertilizer application especially $\mathrm{N}$ was that the soils were deficient in N. Thus, supplying fertilizer-N led to yield increase in the initial phase of the green revolution. However, widespread usage of fertilizer-N mainly in the form of urea resulted in deficiencies of other nutrients that were not applied. Compared to other nutrients, $\mathrm{N}$ is easily dissolved and remains in the solution form making it susceptible to leaching and also surface run-off. Surface applied fertilizer is also subject to loss mechanisms by way of ammonia volatilization and de-nitrification.

*Corresponding author (E-mail: blaise_123@rediffmail.com)
Fertilizer-N that is applied to soil is rapidly transformed and primarily exists in two forms (ammonical and nitrate-N), of which nitrate-N is highly mobile and vulnerable for leaching. Soil moisture is a critical factor that facilitates leaching (Ochsner et al. 2018). Nitrate $\mathrm{N}$ can be easily leached into the deeper layers of the soil profile polluting the ground water which poses a threat to human health (Grizzetti et al. 2011). Livestock health is also adversely affected if fed with nitrate-rich water. Apart from fertilizers, other sources that contribute to nitrate pollution of ground water are manures and crops (Wick et al. 2012) geological sources and precipitation (Viets and Hageman 1971).

Nitrates in ground water

The Environmental Protection Agency USA fixed $45 \mathrm{mg}$ nitrate- $\mathrm{N}^{-1}$ as the safe limit while the 
European Union accepted $50 \mathrm{mg}$ nitrate- $\mathrm{N}^{-1}$ as the safe limit of nitrate in the groundwater. The World Health Organization also set a standard of $45 \mathrm{mg}$ nitrate $\mathrm{l}^{-1}$ more importantly because of a huge consumption of groundwater in the arid and semi-arid regions of developing countries. We accepted the limit set by the WHO.

Presence of nitrate in the water makes it unsafe for drinking purposes (Grizzetti et al. 2011; Ward et al. 2018). Recently several studies across the country have established high proportion of groundwater samples contaminated with nitrate levels more than the safe limit of $45 \mathrm{mg}$ nitrate $\mathrm{l}^{-1}$ (Table 1). Not surprisingly, the first report about high nitrate in ground water originated from the sandy loam soils of Punjab (Arora et al. 1980; Bajwa et al. 1993). Singh et al. (1995) observed two to sevenfolds increase in nitrate concentration over the study period ranging from 1975 to 1993 . The most surprising of the studies were the disclosure of high nitrate pollution of groundwater in the wells of samples collected from Maharashtra (Gupta et al. 2011). The proportion was smaller in the southern states of India (Table 1). However, it should be noted that at some places nitrate content in the tube wells is alarming.

Table 1. Proportion of samples with high nitrate-content in groundwater

\begin{tabular}{lccl}
\hline State & No. of Samples & $\begin{array}{c}\text { No. of samples } \\
\left(\mathbf{N O}_{\mathbf{3}}^{-\mathbf{7}} \mathbf{4 5} \mathbf{~ m ~ ~}^{\mathbf{1}} \mathbf{)}\right.\end{array}$ & Reference \\
\hline Punjab & 470 & 71 & Malik (2000) \\
Haryana & 352 & 68 & Malik (2000) \\
Rajasthan & 64 & & Suthar et al. (2009) \\
Uttar Pradesh & 61 & 37 & Chaudhary (2011) \\
Maharashtra & 1407 & 544 & Gupta et al. (2011) \\
Nalgonda, Telangana & 46 & 6 & Brindha et al. (2012) \\
Karnataka & 6 & 1 & Vinod et al. (2015) \\
\hline
\end{tabular}

\section{Nleaching loss in major agro-ecosystems}

Major intensive cropping systems in the country are rice (Oryza sativa)-wheat (Triticum aestivum), rice-rice, cotton (Gossypium hirsutum)wheat, maize (Zea mays)-based, potato (Solanum tuberosum)-based and sugarcane (Saccharum officinarum)-based cropping systems. Most of these cropping systems are grown on well-endowed lands and is predominantly irrigated and heavily fertilized. Fertilizer use in these cropping systems is in excess of what the crop removes. Furthermore, nitrogen use efficiency ranges from 35 to 60 per cent and the remaining is either lost by volatilization or leaching or remains in the soil.

\section{Present practices and policies - impact on N loss Farm practices}

Rice cultivation became popular in the nontraditional areas such as northwest India and further gained importance in the entire Indo-Gangetic Plains. Rice-wheat is now the most common intensive cropping systems in northwest and north India. The major soil types on which these systems are followed are Inceptisols and Entisols. These soil groups have low clay content and cannot be well puddled. Therefore, these soils are porous and have high infiltration rate. After irrigation, fertilizer-N moves down the soil profile making it conducive to nitrate enrichment of the groundwater (Singh et al. 1995). Further, wheat follows rice in this region which is also highly fertilized. Therefore, the rice-wheat system contributes greatly to 
nitrate pollution of groundwater. Chabbra et al. (2010) opined that this region contributes maximum to the groundwater pollution through nitrate leaching. The northwest India and the Indo-Gangetic plains of north India contributes approximately 0.3 million tonnes of nitrate- $\mathrm{N}$ is added to the ground water every year (Table 2). A conservative estimate of the nitrate loss by major cropping systems is 0.66 million tonnes. This would be much higher if the horticultural crops is accounted and the peri-urban agriculture.

Table 2. Estimated loss of nitrate-N by leaching in the major intensive irrigated cropping systems of India

\begin{tabular}{lc}
\hline Cropping system & Nitrate loss ('000 tonnes)* \\
\hline Rice-wheat & $311.2^{\mathrm{a}}$ \\
Maize based systems & $76.0^{\mathrm{b}}$ \\
Potato based systems & $37.3^{\mathrm{c}}$ \\
Sugarcane based systems & 189.8 \\
Cotton based systems & 44.5
\end{tabular}

*Estimated using leaching factors ${ }^{a}$ Chhabra et al. (2010); ${ }^{b}$ Dash et al. (2015); ${ }^{\circ}$ Sharma (1999)

In central and south India, rice-rice is an intensive cropping system. However, the rice is grown under puddled conditions with fertilizers commonly broadcasted. Leaching is not a major issue under such situations. As nitrogenous fertilizers are readily soluble and are more susceptible to $\mathrm{N}$ loss through volatilization, nitrification-denitrification and run-off(De Datta 1995). Furthermore, fertilizer-N applied suppresses growth of cyanobacteria and biological nitrogen fixation (Ladha et al. 1989).

Cropping systems with a high nitrogenous fertilizer inputs are sugarcane, potato and maize based systems. These cropping systems also contribute sizeable amount of nitrate to the groundwater (Table 2). We obtained the estimates from the proportion of fertilizer-N lost by leaching given by Dash et al. (2015) for maize, Sharma (1999) for potato and multiplied with the average fertilizer- $\mathrm{N}$ use and the acreage. For sugarcane, the proportion of nitrogen lost by leaching for wetland rice was used and for cotton the values for maize because of their similar nature of habitat. Sugarcane fields are wet during most of the period of cane growth making it highly conducive to leaching of fertilizer-N. Potato has a shallow root growth and a heavy feeder. As a result, $\mathrm{N}$ is not efficiently scavenged from the soil and the $\mathrm{N}$ that has moved below the root zone can be lost by leaching. Cotton is a deep rooted crop and can utilize the nitrate present in the lower layers.

Nitrate loss is also a function of the soil type and the management practices followed. A summary of the data for the various locations on which potato was grown is presented in table 3 . It is clear that from the sandy loam soils nearly one-third of the applied fertilizer- $\mathrm{N}$ is lost whereas on the silty loam soils it is half of that observed on the sandy loams. However, the trend is reverse for contribution of losses by surface run off.

Table 3. Leaching and surface run-off of nitrogen from different soil types under potato

\begin{tabular}{lcc}
\hline Soil type & Nitrate leached $\left(\mathrm{kg} \mathrm{ha}^{-1}\right)$ & Surface run-off \\
\hline Silty loam & 14.2 & 5.8 \\
Loam & 16.5 & 5.5 \\
Sandy loam & 30.3 & 4.0 \\
\hline
\end{tabular}




\section{Policies}

Cultivation of rice-wheat cropping system became popular in the northwest and the IGP of north India with the availability of irrigation water, cheap electricity and fertilizer subsidy. Food security concerns were the prime issues and environmental concerns were at the backstage. A combination of all these factors aggravated nitrate pollution of the river basins and the groundwater. Similarly, availability of irrigation water made the rice-rice cropping system a possibility in the southern river plains of Godavari, Cauvery etc. In the mid 90's, de-control of fertilizer pricing resulted in an imbalanced use of fertilizers and greater amounts of nitrogenous fertilizers applied. Urea is the only fertilizer with the prices controlled due to political reasons and thus because of its low cost compared to the other fertilizers, nitrogen is applied in larger amounts.

\section{Strategies and Policies to mitigate leaching and surface run-off}

Strategies

Once $\mathrm{N}$ enters into the soil either through fertilizer or other sources, it is inevitable that the $\mathrm{N}$ on transformations creates a situation for the leaching of excess N. Therefore, efficient management systems and strategies are needed to prevent ground water pollution. An important aspect to be considered is to reduce the $\mathrm{N}$ use during high intensity rainfall events to minimize the nitrate transport to ground waters.

\section{Crop rotation, catch crops and diversification}

This strategy should be designed in a manner that has differential $\mathrm{N}$ requirement and high capacity to utilize $\mathrm{N}$ from the deep layers. For instance potato is heavily fertilized and has a shallow rooting system. It is also grown on soils that are more porous. For such a situation, growing a subsequent crop having a deep root system and a reduced $\mathrm{N}$ supply would be a pragmatic approach. In high $\mathrm{N}$ application regions, $\mathrm{N}$ loss due to leaching can be reduced by growing catch crops or cover crops (Prakasa Rao and Puttana 2006). Growing of crops with low $\mathrm{N}$ demand such as the pulses or crops with low water requirement such as trees are options for reducing $\mathrm{N}$ use and ultimately $\mathrm{N}$ loss to the environment. Singh et al. (2005) reported that pigeon pea could substitute for rice in the rice-wheat cropping system of north India. Adopting agro-forestry systems can also minimize nitrate leaching (Khajanchi-Lal et al. 2015).

\section{Split application}

Singh et al. (2005) suggested split application of fertilizer $\mathrm{N}$ than single application. This is a cheap option to reduce nitrate leaching to ground waters.

\section{Nitrification inhibitors}

Use of nitrification inhibitors can be another alternative to reduce conversion of the ammonium form of $\mathrm{N}$ to nitrate (Wick et al. 2012). Neem cake is an indigenous nitrification inhibitor (Singh et al. 2006, 2011) and is now a component of the fertilizer urea available on the market. There is a sizeable scope of reducing nitrate leaching by the use of such fertilizers.

\section{Deep placement}

In the rice-based cropping systems, the strategy for mitigating surface loss of fertilizer- $\mathrm{N}$ is avoiding broadcast application and adopting the deep placement method of application. Recycling of crop residues along with fertilizer-N in the rice systems will potentially reduce the total fertilizer $\mathrm{N}$ requirements. This would lead to a reduced load on the environment.

\section{Policies}

Policy changes include regulatory approaches and legislative measures making it mandatory for bringing about changes in fertilizer $\mathrm{N}$ use. Subsidy given to fertilizers could also be one of the policy options to be considered. Some changes that may be necessary are briefly discussed below.

\section{Identifying nitrate vulnerable zones}

Once a nitrate vulnerable zone is identified it can be considered for making the region manure/fertilizer free in order to reduce ground water pollution. This can be considered as a priority around the periphery of the regions close to major river water bodies, such as the Ganga, Yamuna, Godavari river basins etc. In such areas, one can opt for low $\mathrm{N}$ requiring crops or adopt a reduction in manure and fertilizer usage which will lessen the pollution of the water bodies. 


\section{Reducingfertilizer-Nusage}

The first and easiest option that is available to minimize leaching loss is to reduce the fertilizer-N input. However, this is to be done carefully as a reduction in $\mathrm{N}$ input may lead to yield reductions that may not be acceptable to the farmer. Therefore, the associated cost of yield loss should be estimated compared to the other technologies that are available.

\section{Removal of subsidy}

Subsidy may be restricted to regions with low fertilizer use whereas regions with excess fertilizer-N application may either be taxed or subsidies offered may be removed. Thus excess $\mathrm{N}$ application can be minimized with an indirect benefit of reduced point and non-point pollution. Nutrient based subsidy can be provided to the fertilizers (NAAS 2012). This way customization and value added fertilizers produced will benefit. Coating of nitrogenous fertilizers with nitrification inhibitors or slow release materials will gain momentum and pave the way for reduced $\mathrm{N}$ loss and improved use efficiency. De-control of the prices of urea and other $\mathrm{N}$ fertilizers can further pave for reduced input and adoption of better agronomic practices.

\section{Introducing value added fertilizers}

Some value added products such as urea super granules may need to be re-introduced. This fertilizer may be of use in the southern states where rice is cultivated under puddled conditions. USG was widely tested in northwest India when the fertilizer product was developed. The product was considered as ineffective in improving use efficiency. Low cation exchange capacity and high percolation rates (Katyal et al. 1988). On the sandy soils, USG may not perform well, but the same may not hold true for the other soil types.

\section{Treatment of well waters}

Wells that are high in nitrate content should either be treated to remove the nitrate or discontinued from use as drinking water or providing water to livestock. Instead, it should be considered as irrigation purpose and restrict use of fertilizer-N.

\section{Challenges ahead}

The irrigated agriculture systems such as the north and northwest have a high potential of leaching because of the combined factors of the permeable soil type, high $\mathrm{N}$ input use. Thus these regions are likely to contribute most to the nitrate leaching. Information on the fertilizer rate that causes nitrate pollution of ground water in the different soil types and cropping systems are far too limited. This has led to several assumptions in the calculation of nitrate in surface and ground water. Therefore, network research programmes should be conducted to validate strategies and identify the critical fertilizer application rates that would result in the pollution of ground water.

Policy changes can be effective only by comparing social costs and societal benefits. No such studies are available for our country at present. Identifying regions that are nitrate vulnerable and making them as manure/fertilizer free, may be in direct contrast to the food security and farm profitability.

\section{References}

Arora, R. P., Sachdev, M. S., Sud, Y. K., Luthra, V. K. and Subbiah, B. V. (1980). Fate of fertilizer nitrogen in a multiple cropping system. In 'Soil nitrogen as fertilizer or pollutant'. pp. 3-22. (IAEA: Vienna).

Bajwa, M. S., Singh, B. and Singh, P. (1993). Nitrate pollution of groundwater under different systems of land management in Punjab. In 'Proceedings of First Agricultural Science Congress'. (Ed. P. Narain) pp. 223-230. (NAAS: New Delhi).

Brindha, K., Rajesh, R., Murugan, R. and Elango, L. (2012). Nitrate pollution in groundwater in some rural areas of Nalgonda district, Andhra Pradesh, India. Journal of Environmental Science Engineering 54, 64-70.

Chaudhary, V. (2011). Nitrate toxicity and possible contaminant sources in groundwater of Western Uttar Pradesh, India. Vegetos 24, 55-61.

Chhabra, A., Manjunath, K. R. and Panigrahy, S. (2010). Non-point source pollution in Indian 
agriculture: Estimation of nitrogen losses from rice crop using remote sensing and GIS. International Journal of Applied Earth Observation and Geoinformation 12, 190-200.

Dash, C., Sarangi, A., Adhikary, P. and Singh, D. (2015). Simulation of nitrate leaching under maizewheat cropping system in a semiarid irrigated area of the Indo-Gangetic Plain, India. Journal of Irrigation and Drainage Engineering, 142, 04015053.

De Datta, S. K. (1995). Nitrogen transformations in wetland rice ecosystems. Fertilizer Research 42, 193-203.

Grizzetti, B., Bouraoui, F., Billen, G., van Grinsven, H., Cardoso, A.C., Thieu, V., Garnier, J., Curtis, C., Howarth, R. and Johnes, P.J. (2011). Nitrogen as a threat to European water quality. In 'The European Nitrogen Assessment'. (Eds. M. A. Sutton, C. M. Howard, J. W. Erisman, G. Billen, A. Bleeker, P. Grennfelt, H. van Grinsven, B. Grizzetti) pp. 379-404. (Cambridge University Press: Cambridge).

Gupta, I., Salunkhe, A., Rohera, N. and Kumar, R. (2011). Groundwater quality in Maharashtra, India: Focus on nitrate pollution. Journal of Environmental Science Engineering 53, 453462.

Katyal, J. C., Singh, B. and Vlek, P. L. G. (1988). Effect of granule size and the placement geometry on the efficiency of urea super granules for wetland rice grown on a permeable soil. Fertilizer Research 15, 193-201.

Khajanchi-Lal, Minhas, P. S. and Yadav, R. K. (2015). Long-term impact of wastewater irrigation and nutrient rates II. Nutrient balance, nitrate leaching and soil properties under peri-urban cropping systems. Agricultural Water Management 156, 110-117.

Ladha, J. K., Miyan, S. and Garcia, M. (1989). Sesbania rostrata as a green manure for lowland rice: Growth, N fixation, Azorhizobium sp. inoculation, and effects on succeeding crop yields and $\mathrm{N}$ balance. Biology and Fertility of Soils 7, 191-197.
Malik, R. P. S. (2000). Agriculture and water quality in India towards sustainable management. In 'Water Quality Management and Control of Water Pollution'. Water Report (FAO, Rome) 21,73-85.

NAAS (2012). Value added fertilizers and site-specific nutrient management (SSNM). Policy Paper No. 57, NAAS, New Delhi.

Ochsner, T. E., Schumacher, T. W., Venterea, R. T., Feyereisen, G. W. and Baker, J. M. (2018). Soil water dynamics and nitrate leaching under corn-soybean rotation, continuous corn and kura clover. Vadose Zone Journal, 17, 1-11.

Prakasa Rao, E. V. S. and Puttana, K. (2006). Strategies for combating nitrate pollution. Current Science 91, 1335-1339.

Sharma, U. C. (1999). Loss of nitrogen through leaching and runoff from two potato land-use systems on different soils. Proceedings of IUGG 99 Symposium HS3, Birmingham, IAHN Publication No. 257, pp. 27-32.

Singh, Ashok, K., Ram, H. and Jagdish Prasad (2011). Urea transformation and yield of $\mathrm{r}$ i c e a s influenced by neem products in three soil tyres. Indian Journal of Fertilizers 7, 12-15.

Singh, Ashok, K., Ram, H., Maurya, B. R. and Jagdish Prasad (2006). Influence of need products on urease activity urea transformation soils and wheat yield. Indian Journal of Fertilizers 2, 45-48.

Singh, B., Singh, Y. and Sekhon, G. S. (1995). Fertilizer$\mathrm{N}$ use efficiency and nitrate pollution of ground water in developing countries. Journal of Contaminant Hydrology 20, 167-174.

Singh, V. K., Dwivedi, B. S., Shukla, A. K., Chauhan, Y. S. and Yadav, R. L. (2005). Diversification of rice with pigeonpea in a rice-wheat cropping system on a Typic Ustochrept: effect on soil fertility, yield and nutrient use efficiency. Field Crops Research 92, 85-105.

Suthar, S., Bishnoi, P., Singh, S., Mutiyar, P. K., Nema, A. K. and Patil, N. S. (2009). Nitrate contamination in groundwater of some rural areas of Rajasthan, India. Journal of Hazardous Materials 171, 189-199. 
Viets, F. G. Jr. and Hageman, R. H. (1971). Factors affecting the accumulation of nitrate in soil, water and plants. U.S. Department of Agriculture, Agricultural Handbook 413, pp. 63.

Vinod, P. N., Chandramouli, P. N. and Koch, M. (2015). Estimation of nitrate leaching in groundwater in an agriculturally used area in the state Karnataka, India, using existing model and GIS. Aquatic Procedia 4, 1047-1053.
Ward, M. H., Jones, R. R., Brender, J. D., de Kok, T. M., Weyer, P. J., Nolan, B. T., Villanueva, C. M. and van Breda, S. G. (2018). Drinking water nitrate and human health: An updated review. International Journal of Environmental Research and Public Health 15, 1557.

Wick, K., Heumesser, C. and Schmid, E. (2012). Groundwater nitrate contamination: Factors and indicators. Journal of Environmental Management 111, 178-186.

Received: August, 2018 Accepted: December, 2018 